\title{
Combining XRF and XRD analyses and sample preparation to solve mineralogical problems
}

\author{
Maggi Loubser and Sabine Verryn \\ X-ray Analytical Facility, Department of Geology, University of Pretoria, Pretoria, 0002, South Africa. \\ e-mail: sabine.verryn@up.ac.za; maggi.loubser@up.ac.za
}

2008 September Geological Society of South Africa

\begin{abstract}
X-ray Fluorescence Spectroscopy (XRF) has reached the stage where it is classified as a mature analytical technique. The theoretical principles are well understood. In addition modern instrumentation demonstrates enhanced generator and temperature stability. High sensitivity is possible even for light elements and effective matrix correction software is available to the modern day spectroscopist. Apart from its continued applications in research and development, XRF has become a routine process control tool.

X-ray Powder diffraction (XRD), on the other hand, has with minor exceptions as in the cement industry, largely remained a research tool, despite being an older analytical technique than XRF. XRD has progressed significantly in the past decade from a mainly qualitative technique for the identification of crystalline materials to a quantitative tool with the advance of more powerful software packages. This software has improved instrument control, but also quantification and structure determination using the Rietveld method. Consequently, XRD is rapidly entering the process control environment.

In this paper the authors demonstrate, with practical examples from different industrial applications, how combined XRF and XRD use can provide truly quantitative phase analyses. XRF is used to verify XRD data and visa versa.

The data obtained in this study clearly illustrate the value that can be added to either technique if XRF and XRD data are used together, and indicate some applications in routine process co.
\end{abstract}

\section{Introduction}

A research laboratory like the X-ray Analytical Facility of the University of Pretoria is exposed to a wide range of materials. Housed by the Geology Department, minerals and ores are routine matrices, but in collaboration with the Department of Metallurgy and Material Science and the Institute for Applied Materials as major users, the laboratory is exposed to many diverse material types. The laboratory is frequently approached by industry regarding problems that commercial laboratories cannot solve, or where high accuracy analysis on specialised matrices is needed. This creates some unique problems that can not always be solved by any single analytical technique and the combined use of XRD and XRF analysis proves an efficient way to solve problems.

$\mathrm{X}$-ray Fluorescence Spectroscopy is used to determine the bulk chemical composition of a sample. Fundamental parameter software like UniQuant ${ }^{\mathrm{TM}}$ (Thermo Fisher Scientific Inc. 2006), enables the qualitative and quantitative analysis of an unknown sample with or without sample preparation. Elements from fluorine to uranium in the periodic table can be analysed with detection limits varying from $0.5 \mathrm{ppm}$ for heavier elements like Mo to $100 \mathrm{ppm}$ for the lightest element $\mathrm{F}$. With the fundamental parameter approach, everything in the sample is analysed to enable accurate matrix corrections. The software allows for manual input of elements not determinable by XRF, like carbon, oxygen and hydrogen in different compounds and this data is then used in the matrix correction model. For higher accuracy, matrix matched calibration curves can be set up for specific matrices with specific sample preparation protocols followed. Examples of calibrations used most often will be shown below.

X-ray Powder Diffraction is used to determine the crystalline phase(s) present in a sample. As each phase has a unique powder diffraction pattern, it is possible to distinguish between compounds as the diffraction method is sensitive to crystal structure and not just composition. The powder diffraction pattern for the spinel $\mathrm{MgAl}_{2} \mathrm{O}_{4}$ looks different from the powder pattern of periclase $(\mathrm{MgO})$ and corundum $\left(\mathrm{Al}_{2} \mathrm{O}_{3}\right)$ mixture although a chemical analysis may show identical results. It is also possible to distinguish between different polymorphic forms of the same compound. Additionally, the intensity of each component's pattern is proportional to the amount present.

Examples of problems encountered where the use of both techniques is of advantage include validation of results when XRF data do not add to $100 \pm 1.5 \%$ without obvious reasons. XRD can confirm the phases present, e.g. carbonates that are not visible to XRF or a mixture of components with differing oxidation states. XRF determines total iron and / or titanium, but for matrix correction purposes adds stoichiometric amounts of oxygen according to the most common oxidation states. In the case of mixtures of hematite and magnetite or illmenite and rutile, this could lead to erroneous results. The analysis of slag and refractory materials are other examples where additional XRD information is crucial to successful analysis. Slag samples often contain traces of metal. The XRF software either assigns oxygen or treats a sample as a metal, and consequently mixtures pose problems. In addition, sulphur and silicon are of the few elements that show a peak shift in XRF depending on 
the oxidation state (Willis and Duncan 2008). If a system was set up using oxide materials and a sulphide or silicon metal is analysed, a peak shift will lead to erroneous results. XRD can easily be used to identify these problems.

Metal inclusions also pose serious risks to routine sample preparation procedures, as major element analysis is usually determined on fused lithium borate beads. Metals, exposed to platinum ware at elevated temperatures, form low melting ligands that react with the platinum laboratory ware (Lupon et al. 1997). Sulphide bearing materials have the same tendency.

In these cases XRD is used to identify possible deleterious elements in the sample and also to confirm that all metals and sulphides were oxidized during pretreatment before fusion.

\section{Analytical procedures}

\section{XRF}

Bulk sample preparation consists of drying where necessary, crushing to $10 \mathrm{~mm}$, riffle splitting and milling in a tungsten carbide milling pot to ca. $80 \%$ below $75 \mu \mathrm{m}$. When Co and $\mathrm{W}$ analysis are specifically requested a carbon steel milling vessel is used. For XRD contamination from milling vessels is only a factor when material harder than that of the grinding medium is milled and here corundum as well as Si-carbides have been observed to be problematic.

Samples are dried at $110^{\circ} \mathrm{C}$ (Weight 1) and roasted at $1000^{\circ} \mathrm{C}$ (Weight 2 ), to determine the percentage loss on ignition (LOI) using the following equation:

$$
\% L O I=\frac{\text { Weight }_{1}-\text { Weight }_{2}}{\text { Weight }_{1}-\text { Weight }_{\text {crucible }}} \times 100
$$

Major element analyses are executed on fused beads, following a method adapted from $\mathrm{H}$. Bennett and $\mathrm{G}$. Oliver's proposed methods (1992). $1 \mathrm{~g}$ pre-roasted sample is added to $6 \mathrm{~g}$ of lithium tetraborate $\left(\mathrm{Li}_{2} \mathrm{~B}_{4} \mathrm{O}_{7}\right)$ flux mixed in a $5 \% \mathrm{Au} / \mathrm{Pt}$ crucible and fused at $1000^{\circ} \mathrm{C}$ in a muffle furnace automated fluxer (Beadmaster F-M4). A mouldable crucible is used so that, on removal from the furnace, the bead is fast cooled in the crucible of which the bottom surface is analysed. This approach has the advantage, that should there be undissolved material, it is all retained in the bead which can be remelted.

Trace elements are analysed on pressed powder briquettes, after an adaptation of the method described by Watson (1996), using a saturated solution of polyvinyl alcohol 40-88, as binder. The mixing of the sample and binder is accomplished in a plastic zip-lock bag. $20 \mathrm{~g}$ of $75 \mu \mathrm{m}$ powder is mixed with a few drops of polyvinyl alcohol and pressed at a pressure of $20 \mathrm{ton} / \mathrm{cm}^{2}$ for two minutes in collapsible aluminium holders for mechanical support, using a polished piston. The sample is then dried at $110^{\circ} \mathrm{C}$ before analysis.
Special sample preparation techniques have been developed for non-routine materials. Sulphide containing materials have to be prepared with special care as sulphides are not soluble in lithium borate fluxes and damage the platinum ware (Lupon et al. 1997). These samples have to be pre-oxidised while retaining the sulphur quantitatively as $\mathrm{SO}_{4}$. This is accomplished by using Lithium nitrate $\left(\mathrm{LiNO}_{3}\right), 0.5 \mathrm{~g}$ of sample is thoroughly mixed with $3 \mathrm{~g}$ of $\mathrm{LiNO}_{3}$ and placed on a bed of $(3 \mathrm{~g}) \mathrm{Li}_{2} \mathrm{~B}_{4} \mathrm{O}_{7}$ and covered with the remaining ( $\left.3 \mathrm{~g}\right)$ flux. This "sandwich" technique protects the platinum against un-oxidised sulphides and at the same time the flux lid helps to prevent the escape of any $\mathrm{SO}_{2}$ gas. The mixing of sample and oxidant is crucial to facilitate complete oxidation. The pre-reaction is done at much lower temperatures than suggested in the literature (Sear L G. 1997), as it was found that sulphur is lost when oxidation reactions are executed at temperatures above the dissociation of $\mathrm{LiNO}_{3}\left(600^{\circ} \mathrm{C}\right)$. A method was developed where the sample is pre-reacted for an hour in a muffle furnace at $500^{\circ} \mathrm{C}$, above the melting temperature of $\mathrm{LiNO}_{3}$ but below the dissociation temperature. The reaction was evaluated using Differential Scanning Calorimetry (DSC) and XRD to evaluate the reaction and confirm completion of the oxidation, before heating to $1000^{\circ} \mathrm{C}$ for the fusion to take place.

Metal bearing samples, like industrial refractory materials where a brick / metal interface exists, as well as modern refractory materials where metallic particles and graphite are added for increased strength, need special preparation. The same preparation methods are used for slag samples where metallic residues are often present. To prepare these samples for XRF analysis, a pre-oxidation step using nitric acid $\left(\mathrm{HNO}_{3}\right)$, is used as roasting was found to be ineffective. Roasting forms a oxidised layer on the outer surface of the particles, protecting the inside against further reaction and, when dissolved by the flux during fusion, the metallic residue is brought into direct contact with the platinum crucible. The method used is as follows: $1 \mathrm{~g}$ sample is weighed directly into a platinum crucible and $5 \mathrm{ml}$ of a $50 \%$ aqueous $\mathrm{HNO}_{3}$ solution is added. The mixture is heated slowly on a hot plate until all reaction ceases and dries. Then $6 \mathrm{~g}$ of lithium tetraborate flux is added on top and fused at $1000^{\circ} \mathrm{C}$ as usual. As roasting could not be used to determine the loss or gain on ignition, the fused bead is weighed, and the difference in sample mass before and after oxidation is calculated.

The instrumentation used is an ARL 9400XP+ Wavelength dispersive XRF Spectrometer with a Rhodium tube, LiF200, LiF220, GER, AXO6 (a 50Å synthetic multilayer) and PET analysing crystals, with a flow proportional and scintillation detector. Data reduction is performed using three different software approaches: WINXRF using the COLA algorithm (Lachance and Claisse, 1980) with theoretical alphas deduced from fundamental parameters, for matrix correction of fused bead major elements as well as 
Table 1. Instrumental parameters for Majors program.

\begin{tabular}{|c|c|c|c|c|c|c|c|}
\hline Analyte & o $2 \theta$ & $\begin{array}{l}\text { Crystal } \\
\text { detector }\end{array}$ & $\begin{array}{l}\text { Collimator } \\
\text { ('divergence) }\end{array}$ & $\begin{array}{l}\text { Time } \\
\text { (s) }\end{array}$ & Interference & $\begin{array}{l}\text { Highest } \\
\text { conc. }(\%)\end{array}$ & $\mathbf{k V} / \mathbf{m A}$ \\
\hline \multirow[t]{2}{*}{$\operatorname{SiK} \alpha 1,2$} & 109.01 & PET & 0.6 & 20 & - & 100 & $30 / 80$ \\
\hline & & FPC & & & & & \\
\hline \multirow[t]{2}{*}{ TiK $\alpha 1,2$} & 86.17 & LiF200 & 0.15 & 20 & - & 3.77 & $50 / 50$ \\
\hline & & FPC & & & & & \\
\hline \multirow[t]{2}{*}{$\mathrm{AlK} \alpha 1,2$} & 144.619 & PET & 0.25 & 20 & $\mathrm{Br}$ & 100 & $30 / 80$ \\
\hline & & FPC & & & & & \\
\hline \multirow[t]{2}{*}{$\mathrm{FeK} \alpha 1,2$} & 57.518 & LiF200 & 0.15 & 20 & $\mathrm{Mn}$ & 50.00 & $50 / 50$ \\
\hline & & FPC & & & & & \\
\hline \multirow[t]{2}{*}{$\operatorname{MnK} \alpha 1,2$} & 62.973 & LiF200 & 0.25 & 20 & $\mathrm{Cr}$ & 0.35 & $50 / 50$ \\
\hline & & FPC & & & & & \\
\hline \multirow[t]{2}{*}{$\operatorname{MgK} \alpha 1,2$} & 19.878 & AX06 & 0.60 & 100 & $\mathrm{Zr} 2 \mathrm{nd}$ order & 43.51 & $30 / 80$ \\
\hline & & FPC & & & PHS corrects & & \\
\hline \multirow[t]{2}{*}{$\mathrm{CaK} \alpha 1,2$} & 113.086 & LiF200 & 0.25 & 20 & - & 100.0 & $30 / 80$ \\
\hline & & FPC & & & & & \\
\hline \multirow[t]{2}{*}{$\operatorname{NaK} \alpha 1,2$} & 23.993 & AX06 & & & & & \\
\hline & & FPC & 0.60 & 100 & $\mathrm{Zn}$ & 5.84 & $30 / 80$ \\
\hline \multirow[t]{2}{*}{$\mathrm{KK} \alpha 1,2$} & 136.637 & LiF200 & 0.6 & 20 & - & 8.91 & $30 / 80$ \\
\hline & & FPC & & & & & \\
\hline \multirow[t]{2}{*}{$\mathrm{PK} \alpha 1,2$} & 140.952 & Ge111 & 0.60 & 20 & Ca not & 39.96 & $30 / 80$ \\
\hline & & FPC & & & relevant (Ge) & & \\
\hline \multirow[t]{2}{*}{$\operatorname{CrK} \alpha 1,2$} & 69.354 & LiF200 & 0.25 & 100 & - & 3.5 & $50 / 50$ \\
\hline & & FPC & & & & & \\
\hline \multirow[t]{2}{*}{ NiK $\alpha 1,2$} & 48.667 & LiF200 & 0.25 & 100 & $\mathrm{Yb}$ & 0.48 & $50 / 50$ \\
\hline & & FPC & & $50+50$ & $\begin{array}{l}\text { Y2nd PHS, } \\
\text { tube impurities }\end{array}$ & & \\
\hline \multirow[t]{2}{*}{ VK $\alpha 1,2$} & 76.933 & $\mathrm{LiF} 200$ & 0.25 & 100 & $\mathrm{Ti}$ & 0.09 & $50 / 50$ \\
\hline & & FPC & & & & & \\
\hline \multirow[t]{2}{*}{$\mathrm{ZrK} \alpha 1,2$} & 32.038 & LiF220 & 0.15 & 20 & $\mathrm{Sr}$ & 0.1 & $50 / 50$ \\
\hline & & SC & & & & & \\
\hline \multirow[t]{2}{*}{$\operatorname{SrK} \alpha 1,2$} & 35.796 & $\mathrm{LiF} 220$ & 0.15 & 20 & & 0.52 & $50 / 50$ \\
\hline & & SC & & & & & \\
\hline \multirow[t]{2}{*}{$\mathrm{ZnK} \alpha 1,2$} & 41.794 & LiF200 & 0.25 & 100 & & 0.92 & $50 / 50$ \\
\hline & & SC & & & & & \\
\hline \multirow[t]{2}{*}{ CuK $\alpha 1,2$} & 45.030 & LiF200 & 0.25 & 100 & $\mathrm{Sr}$ & 0.7800 & $50 / 50$ \\
\hline & & FPC & & +50 & tube impurity & & \\
\hline \multirow[t]{2}{*}{$\mathrm{SK} \alpha 1,2$} & 110.688 & Ge111 & 0.60 & 100 & & 0.4 & $30 / 80$ \\
\hline & & FPC & & $50+50$ & & & \\
\hline
\end{tabular}

PET - Peta-erythritol

LiF - Lithium fluoride

Ge - Germanium

FPC - Flow proportional Counter

SC - Scintillation Counter

AX06 - Layered synthetic microstructure

powder majors and trace element analysis of $\mathrm{Cl}, \mathrm{Co}, \mathrm{Cr}$, $\mathrm{V}, \mathrm{Sc}$ and S. The Rhodium Compton peak ratio method (Feather and Willis. 1976) is used for the other trace elements.

The XRF Spectrometer is calibrated with certified reference materials, specpure oxides and some in-house standards, e.g. Specpure $\mathrm{AL}_{2} \mathrm{O}_{3}, \mathrm{AGV}-1, \mathrm{BCR}-1, \mathrm{BE}-\mathrm{N}$, BHVO-1, BR, Specpure $\mathrm{CaCO}_{3}$, Specpure $\mathrm{CaO}$, DR-N, $\mathrm{FeCa}$ (in-house), FeSi (in-house), GA, GS-N, GSP-1, Specpure $\mathrm{SiO}_{2}$, JB-1, JG-1, Lithium tetraborate blank, MA-N, Mica-Fe, Mica-Mg, MRG-1, NIM-D (SARM 6), NIM-
G (SARM1), NIM-N (SARM4), NIM-P (SARM5), NIM-S (SARM2), PCC-1, SARM8, SARM9, SARM32, SARM34, SARM39, SARM40, SARM42, SARM44, SARM45, SARM46, SARM47, SARM49, SY-2, SY-3, UB-N, UREM3, UREM4, UREM7, W-2 (Govindaraju, K. 1984).

Background and overlap corrections were calculated on a set of interference standards and stored in the calibration according to a method proposed by Willis and Duncan (1993).

Tables 1 to 4 show the instrumental parameters for the three analytical approaches: 
Table 2. Instrumental parameters for Trace elements

\begin{tabular}{|c|c|c|c|c|c|c|c|}
\hline Analyte & ${ }^{\circ} 2 \theta$ & $\begin{array}{l}\text { Crystal } \\
\text { detector }\end{array}$ & $\begin{array}{l}\text { Collimator } \\
\text { ('divergence) }\end{array}$ & $\begin{array}{l}\text { Time } \\
\text { (s) }\end{array}$ & Interference & $\begin{array}{l}\text { Highest } \\
\text { conc. (\%) }\end{array}$ & $\mathbf{k V} / \mathbf{m A}$ \\
\hline \multirow[t]{2}{*}{ CuK $\alpha 1,2$} & 45.030 & LiF200 & 0.25 & 20 & $\mathrm{Sr}$, tube impurity & 0.7800 & $50 / 50$ \\
\hline & & $\mathrm{SC}$ & & $10+10$ & & & \\
\hline \multirow[t]{2}{*}{$\mathrm{NiK} \alpha 1,2$} & 48.667 & LiF2000 & 25 & 20 & $\mathrm{Yb}$ & 0.26 & $50 / 50$ \\
\hline & & $\mathrm{SC}$ & & $10+10$ & $\begin{array}{l}\text { Y2nd PHS, tube } \\
\text { impurities }\end{array}$ & & \\
\hline \multirow[t]{2}{*}{$\mathrm{ClK} \alpha 1,2$} & 92.76 & Ge111 & 0.60 & 100 & & 0.1161 & $30 / 80$ \\
\hline & & FPC & & $50+50$ & & & \\
\hline \multirow[t]{2}{*}{$\operatorname{CoK} \alpha 1,2$} & 52.8 & LiF200 & 0.25 & 100 & & 0.0267 & $50 / 50$ \\
\hline & & FPC & & +50 & & & \\
\hline \multirow[t]{2}{*}{$\operatorname{ScK} \alpha 1,2$} & 97.72 & LiF200 & 0.15 & 100 & & 0.0064 & $50 / 50$ \\
\hline & & FPC & & $50+50$ & & & \\
\hline \multirow[t]{2}{*}{$\mathrm{FK} \alpha 1,2$} & 37.236 & AX06 & 0.60 & 100 & & 2.85 & $30 / 80$ \\
\hline & & FPC & & $50+50$ & & & \\
\hline \multirow[t]{2}{*}{$\mathrm{BaL} \alpha 1,2$} & 87.17 & LiF200 & 0.15 & 100 & & 0.45 & $50 / 50$ \\
\hline & & FPC & & $50+50$ & & & \\
\hline \multirow[t]{2}{*}{$\operatorname{LaL} \alpha 1,2$} & 82.95 & LiF200 & 0.15 & 100 & & 0.27 & $50 / 50$ \\
\hline & & FPC & & $50+50$ & & & \\
\hline \multirow[t]{2}{*}{$\operatorname{CeL} \alpha 1,2$} & 79.010 & LiF200 & 0.15 & 100 & & 0.27 & $50 / 50$ \\
\hline & & FPC & & +50 & & & \\
\hline \multirow[t]{2}{*}{ CsL $\alpha 1,2$} & 91.823 & LiF200 & 0.15 & 100 & & 0.02 & $50 / 50$ \\
\hline & & FPC & & $50+50$ & & & \\
\hline \multirow[t]{2}{*}{$\mathrm{GaK} \alpha 1,2$} & 38.917 & LiF200 & 0.25 & 20 & & 0.0095 & $50 / 50$ \\
\hline & & SC & & $10+10$ & & & \\
\hline \multirow[t]{2}{*}{$\operatorname{MoK} \alpha 1,2$} & 28.843 & LiF220 & 0.15 & 40 & $\mathrm{Zr}, \mathrm{U}$ & 0.0330 & $50 / 50$ \\
\hline & & $\mathrm{SC}$ & & $20+20$ & & & \\
\hline \multirow[t]{2}{*}{$\mathrm{NbK} \alpha 1,2$} & 30.378 & LiF220 & 0.15 & 20 & Y, Th & 0.0270 & $50 / 50$ \\
\hline & & SC & & $20+20$ & & & \\
\hline \multirow[t]{2}{*}{ PbL $\alpha 1,2$} & 40.379 & LiF220 & 0.15 & 20 & & 2.82 & $50 / 50$ \\
\hline & & SC & & $10+10$ & & & \\
\hline \multirow[t]{2}{*}{$\mathrm{RbK} \alpha 1,2$} & 37.929 & LiF220 & 0.15 & 20 & $\mathrm{U}$ & 0.2200 & $50 / 50$ \\
\hline & & $\mathrm{SC}$ & & $10+10$ & & & \\
\hline \multirow[t]{2}{*}{$\operatorname{SrK} \alpha 1,2$} & 35.793 & $\mathrm{LiF} 220$ & 0.15 & 20 & & 0.1600 & $50 / 50$ \\
\hline & & SC & & $10+10$ & & & \\
\hline \multirow[t]{2}{*}{ ThL $\alpha 1,2$} & 39.227 & LiF220 & 0.15 & 40 & & 0.0150 & $50 / 50$ \\
\hline & & $\mathrm{SC}$ & & $10+10$ & & & \\
\hline \multirow[t]{2}{*}{$\mathrm{UL} \alpha 1,2$} & 37.295 & LiF220 & 0.15 & 40 & & 0.0080 & $50 / 50$ \\
\hline & & SC & & $20+20$ & & & \\
\hline \multirow[t]{2}{*}{$\mathrm{YK} \alpha 1,2$} & 33.839 & $\mathrm{LiF} 220$ & 0.15 & 20 & $\mathrm{Rb}, \mathrm{Th}$ & 0.0143 & $50 / 50$ \\
\hline & & SC & & $10+10$ & & & \\
\hline \multirow[t]{2}{*}{$\mathrm{ZnK} \alpha 1,2$} & 41.799 & LiF200 & 0.25 & 20 & Tube impurities & 0.9083 & $50 / 50$ \\
\hline & & SC & & $10+10$ & & & \\
\hline \multirow[t]{2}{*}{$\mathrm{ZrK} \alpha 1,2$} & 32.032 & LiF220 & 0.15 & 20 & Sr,Th, tube impurities & 0.0943 & $50 / 50$ \\
\hline & & SC & & $10+10$ & & & \\
\hline \multirow[t]{2}{*}{ AsK $\alpha 1,2$} & 43.5500 & LiF200 & 0.15 & 40 & $\mathrm{Ba}$ and $\mathrm{Rh}$ & 0.0121 & $50 / 50$ \\
\hline & & SC & & $10+10$ & & & \\
\hline WL $\alpha 1,2$ & 43.001 & LiF200 & 0.15 & 20 & & 0.0450 & $50 / 50$ \\
\hline & & SC & & $10+10$ & & & \\
\hline
\end{tabular}

PET - Peta-erythritol

LiF - Lithium fluoride

$\mathrm{Ge}$ - Germanium

FPC - Flow proportional Counter

SC - Scintillation Counter

AX06 - Layered synthetic microstructure 
Table 3. Instrumental parameters for corrections

\begin{tabular}{|c|c|c|c|c|c|c|}
\hline Analyte & ${ }^{\circ} 2$ & $\begin{array}{l}\text { Crystal } \\
\text { detector }\end{array}$ & $\begin{array}{l}\text { Collimator } \\
\text { ('divergence) }\end{array}$ & Time & Interference & $\mathbf{k V} / \mathbf{m A}$ \\
\hline \multirow[t]{2}{*}{ RhKacompton } & 26.345 & $\mathrm{LiF} 220$ & 0.15 & 20 & Feather Willis correction & $50 / 50$ \\
\hline & & SC & & & & \\
\hline \multirow[t]{2}{*}{ RhKacompton } & 18.549 & LiF200 & 0.15 & 20 & Feather Willis correction & $50 / 50$ \\
\hline & & SC & & & & \\
\hline \multirow[t]{2}{*}{$\operatorname{RhK} \alpha$} & 24.899 & $\mathrm{LiF} 220$ & 0.15 & 20 & Tube impurities correction & $50 / 50$ \\
\hline & & SC & & & & \\
\hline \multirow[t]{2}{*}{$\mathrm{RhK} \alpha$} & 17.563 & LiF200 & 0.15 & 20 & Tube impurities correction & $50 / 50$ \\
\hline & & SC & & & & \\
\hline
\end{tabular}

Table 4. Instrumental parameters for UniQuant.

\begin{tabular}{lllllll}
\hline Crystal & 2d Crystal & $\begin{array}{l}\text { Collimator } \\
\text { ('divergence) }\end{array}$ & Detector & $\begin{array}{l}\text { X-Ray tube } \\
\text { anode }\end{array}$ & \multicolumn{2}{c}{ Tube setting } \\
LiF220 & 2.8480 & 0.15 & SC & Rh & 60 & Primary beam filter \\
LiF420 & 1.8000 & 0.15 & SC & Rh & 60 & 40 \\
LiF220 & 2.8480 & 0.15 & FPC & Rh & 40 & 40 \\
GE111 & 6.5320 & 0.15 & FPC & Rh & 40 & 60 \\
AX06 & 55.400 & 0.60 & FPC & Rh & 30 & 60 \\
\hline
\end{tabular}

AX06 - Layered synthetic microstructure

As part of ongoing quality control, a blank and two certified reference materials are analysed with each batch of samples. Each tenth sample is run in duplicate and clients are encouraged to include their own standards and duplicates in batches. The laboratory participates in the International Association for Geoanalysts' GeoPT proficiency test (Thompson et. al.,1997) where geological materials are analysed three times a year, and results reported after statistical treatment with " $z$ " values for each element from each laboratory. To evaluate sample preparation errors, an inhouse standard is submitted monthly with a batch of unknowns and prepared in the same manner as unknowns. Reported standard deviations are expressed as the standard deviation of a calibration curve, set up with an average of 20-30 standards, as this method best approximates the entire calibration range. Limits of Quantification were also calculated from calibration standards. (Table 5)

\section{XRD}

At the X-ray Analytical Facility at the University of Pretoria samples are analysed using a PANalytical X'Pert Pro powder diffractometer with X'Celerator detector and variable divergence- and receiving slits each set at between 5 and $15 \mathrm{~mm}$, depending on the sample holder used. The samples are scanned at the required $2 \theta$ angle ranges. The radiation can be Fe-filtered $\operatorname{CoK} \alpha$, Ni-filtered $\mathrm{CuK} \alpha$ or Mn-filtered FeK $\alpha$ radiation depending on the chemical composition of the samples analyzed in order

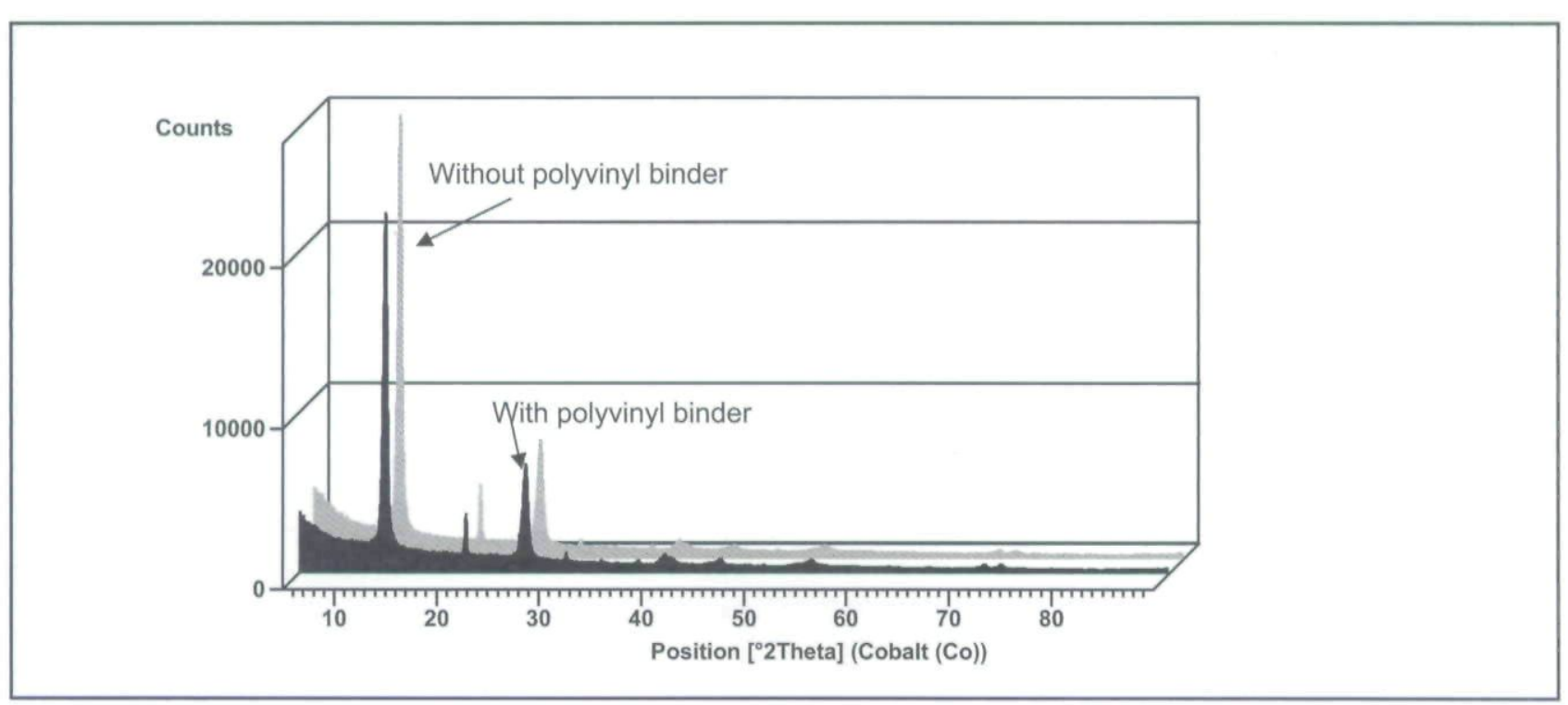

Figure 1. Effect of polyvinyl alcohol binder on XRD scans of pressed powder briquettes 
Table 5. Standard deviation and Limit of Quantification.

\begin{tabular}{|c|c|c|}
\hline & std dev.(\%) & LOQ. $(\%)$ \\
\hline $\mathrm{SiO}_{2}$ & 0.4 & 0.02 \\
\hline $\mathrm{TiO}_{2}$ & 0.03 & 0.0032 \\
\hline $\mathrm{Al}_{2} \mathrm{O}_{3}$ & 0.3 & 0.01 \\
\hline $\mathrm{Fe}_{2} \mathrm{O}_{3}$ & 0.3 & 0.0097 \\
\hline $\mathrm{MnO}$ & 0.0065 & 0.0013 \\
\hline $\mathrm{MgO}$ & 0.1 & 0.0118 \\
\hline $\mathrm{CaO}$ & 0.07 & 0.01 \\
\hline $\mathrm{Na}_{2} \mathrm{O}$ & 0.11 & 0.0265 \\
\hline $\mathrm{K}_{2} \mathrm{O}$ & 0.06 & 0.005 \\
\hline $\mathrm{P}_{2} \mathrm{O}_{5}$ & 0.08 & 0.01 \\
\hline $\mathrm{Cr}_{2} \mathrm{O}_{3}$ & 0,0053 & 0.0006 \\
\hline $\mathrm{NiO}$ & 0.01 & 0.0013 \\
\hline $\mathrm{V}_{2} \mathrm{O}_{5}$ & 0.0018 & 0.0008 \\
\hline $\mathrm{ZrO}_{2}$ & 0.005 & 0.0009 \\
\hline \multirow[t]{2}{*}{$\mathrm{CuO}$} & 0.0037 & 0.0003 \\
\hline & std dev.(ppm) & LOQ.(ppm) \\
\hline As & 10 & 3 \\
\hline $\mathrm{Cu}$ & 3 & 2 \\
\hline $\mathrm{Ga}$ & 2 & 2 \\
\hline Mo & 1 & 1 \\
\hline $\mathrm{Nb}$ & 3 & 2 \\
\hline $\mathrm{Ni}$ & 6 & 3 \\
\hline $\mathrm{Pb}$ & 3 & 3 \\
\hline $\mathrm{Rb}$ & 4 & 2 \\
\hline $\mathrm{Sr}$ & 4 & 3 \\
\hline Th & 2 & 3 \\
\hline U & 2 & 3 \\
\hline W & 10 & 6 \\
\hline $\mathrm{Y}$ & 4 & 3 \\
\hline $\mathrm{Zn}$ & 4 & 4 \\
\hline $\mathrm{Zr}$ & 6 & 10 \\
\hline $\mathrm{Ba}$ & 14 & 5 \\
\hline $\mathrm{Ce}$ & 14 & 6 \\
\hline $\mathrm{Cl}$ & 100 & 11 \\
\hline Co & 6 & 3 \\
\hline $\mathrm{Cr}$ & 40 & 15 \\
\hline $\mathrm{F}$ & 500 & 100 \\
\hline $\mathrm{La}$ & 24 & 5 \\
\hline S & 300 & 40 \\
\hline Sc & 5 & 1 \\
\hline V & 10 & 1 \\
\hline
\end{tabular}

to eliminate fluorescence which would cause, high background and poor peak to background ratio. The phases are identified using PANalytical X'Pert Highscore plus software.

When required, relative phase amounts are estimated by the Rietveld method using either the Autoquan BGMN Rietveld Program (Kleeberg and Bergmann, 1998; 2002, Kleeberg et al., 2000) or topas from Bruker AXS employing the fundamental parameter approach or PANalytical X'Pert Highscore plus software.

Various sample preparation methods are employed. For routine analysis on powders a back loading preparation method is used. Front Loading onto a zero background Silicon sample disc is used when the sample amount is too small for the routine samples holders. Solid sample fragments which cannot be powdered (e.g. metals and plastics) are mounted in a sample cup. In certain instances it is possible to use the same powder briquettes prepared for XRF analysis. The effect of the additional polyvinyl binder was investigated and found to be negligible (Figure 1).

For routine phase identification a particle size of less than $50 \mu \mathrm{m}$ is required, which is achieved by milling in a tungsten carbide or carbon steel milling vessel using a swing mill or even by hand grinding in an agate mortar and pestle. For quantitative phase analysis, the preferred particle size is below $10 \mu \mathrm{m}$ and that is reached by wet grinding for between five and ten minutes using ethanol in a McCrone micronizing mill (Klug and Alexander, 1974; Buhrke et al., 1998). When the determination of amorphous content is required, a known amount of a standard, usually 15 or $20 \% \mathrm{Si}$ (Aldrich $99 \%$ pure), is added to a milled sample and the sample and standard are homogenized in a McCrone micronizing mill.

In order to test the reproducibility of phase quantification using Rietveld analyis the analysis of iron ore sinters, as discussed below, is used as an example. Three tests were performed:

1. The same sample mount was analyzed ten times to test the reproducibility of the instrument and method.

2. To test the reproducibility of sample packing and sample presentation to the beam the same subsample was remounted ten times and re-analysed.

3. The homogeneity and representativeness of sub-samples was tested by taking ten different sub-samples and repeating the sample preparation and mounting procedure. In each case 16.6 weight per cent $\mathrm{Si}$ powder (Aldrich, 99\% purity) for verification of results was added. The results are presented in Table 6.

\section{Case studies \\ Iron Ore Sinters}

Iron ore sinters are important feedstock materials for the steel industry. As a result of increased quality requirements, the chemistry and the phase composition of sinters are of importance. Historically point counting was used in the analysis of theses sinters. Quantitative $\mathrm{X}$-ray powder diffraction analysis, however, is another method for determination of the relative quantities of phases present in sinters. Although no observations on textural features can be made, it is fast and can easily be adapted for process control.

Minerals typically present in the sinters are magnetite, hematite, magnesioferrite, periclase, dicalcium silicate, glass and silico ferrites of calcium and aluminium. The latter phases are abbreviated as SFCA, of which three varieties have been described depending on the molar ratio of cations to oxygen: SFCA $\left(\mathrm{M}_{14} \mathrm{O}_{20}\right)$, SFCA-I $\left(\mathrm{M}_{20} \mathrm{O}_{28}\right)$ and SFCA-II $\left(\mathrm{M}_{26} \mathrm{O}_{36}\right)(\mathrm{M}=\mathrm{Ca}, \mathrm{Fe}, \mathrm{Al}$ and $\mathrm{Si})$. The four sinter samples used in this example were obtained from Mittal Steel SA. 20\% Si powder (Aldrich, 
Table 6. Representativeness of XRD preparation

\begin{tabular}{|c|c|c|c|c|c|c|c|}
\hline & C2S & Hematite & Magnetite & SFCA I & SFCA & SFCAII & Silicon \\
\hline \multicolumn{8}{|c|}{ Identical sample mount } \\
\hline Mean & 9.30 & 8.91 & 23.81 & 3.54 & 15.31 & 22.46 & 16.22 \\
\hline Standard Deviation & 0.54 & 0.16 & 0.51 & 0.98 & 1.54 & 1.37 & 0.26 \\
\hline \multicolumn{8}{|c|}{ Same subsample - Different sample mount } \\
\hline Mean & 9.35 & 9.01 & 23.80 & 3.25 & 15.56 & 22.46 & 16.17 \\
\hline Standard Deviation & 0.49 & 0.23 & 0.57 & 0.61 & 1.28 & 1.46 & 0.36 \\
\hline \multicolumn{8}{|c|}{ Different subsamples } \\
\hline Mean & 9.16 & 9.04 & 23.76 & 3.53 & 15.54 & 22.35 & 16.19 \\
\hline Standard Deviation & 0.54 & 0.43 & 0.52 & 0.97 & 1.69 & 1.37 & 0.43 \\
\hline
\end{tabular}

Table 7. Quantitative XRD data of Iron Ore Sinters used in the study.

\begin{tabular}{lllllll}
\hline & C2S & Hematite & Magnetite & SFCA & SFCA II & Silicon \\
\hline Sinter 1 & 7.47 & 11.02 & 21.93 & 34.10 & 13.17 & 13.67 \\
Sinter 2 & 5.66 & 12.17 & 29.39 & 33.24 & 12.69 & 8.75 \\
Sinter 3 & 6.08 & 19.82 & 32.26 & 14.37 & 13.32 \\
Sinter 4 & 6.02 & & 10.63 & 9.82 & 20.83 \\
\hline
\end{tabular}

Table 8. XRF data on Sinter samples (weight \%).

\begin{tabular}{|c|c|c|c|c|}
\hline & Sinter 1 & Sinter 2 & Sinter 3 & Sinter 4 \\
\hline $\mathrm{SiO}_{2}$ & 4.21 & 4.51 & 4.63 & 4.2 \\
\hline $\mathrm{TiO}_{2}$ & 0.09 & 0.09 & 0.08 & 0.09 \\
\hline $\mathrm{Al}_{2} \mathrm{O}_{3}$ & 1.24 & 1.27 & 1.32 & 1.23 \\
\hline $\mathrm{Fe}_{2} \mathrm{O}_{3}$ & 61.3 & 57.28 & 57.68 & 60.9 \\
\hline $\mathrm{MnO}$ & 86 & 0.96 & 0.78 & 0.91 \\
\hline $\mathrm{MgO}$ & 2.7 & 2.84 & 2.9 & 2.68 \\
\hline $\mathrm{CaO}$ & 9.07 & 9.07 & 10.51 & 8.64 \\
\hline $\mathrm{Na}_{2} \mathrm{O}$ & $<0.005$ & $<0.005$ & $<0.005$ & $<0.005$ \\
\hline $\mathrm{K}_{2} \mathrm{O}$ & 0.13 & 0.14 & 0.13 & 0.13 \\
\hline $\mathrm{P}_{2} \mathrm{O}_{5}$ & 0.1 & 0.1 & 0.12 & 0.1 \\
\hline $\mathrm{Cr}_{2} \mathrm{O}_{3}$ & 0.02 & 0.02 & 0.02 & 0.02 \\
\hline $\mathrm{NiO}$ & $<0.01$ & $<0.01$ & $<0.01$ & $<0.01$ \\
\hline $\mathrm{V}_{2} \mathrm{O}_{3}$ & $<0.01$ & $<0.01$ & $<0.01$ & $<0.01$ \\
\hline $\mathrm{ZrO}_{2}$ & $<0.01$ & $<0.01$ & $<0.01$ & $<0.01$ \\
\hline LOI & 19.41 & 23.09 & 21.94 & 20.35 \\
\hline Total & 99.15 & 99.37 & 100.11 & 99.25 \\
\hline
\end{tabular}

$99 \%$ purity) for determination of amorphous content as well as verification of results was added. More detailed XRD results are shown in de Villiers and Verryn (2007).

These results are a first approximation and minor phases were ignored, recalculation including minor phases can improve the results. Ignoring the added Si, these results are in good agreement with the results obtained by XRF, and in this case the analytical totals are acceptable. From the XRD results we obtain information about the oxidation states of most of the $\mathrm{Fe}$ in the sample (Tables 7 and 8).

\section{Analysis of Fly Ash and other glass containing materials}

At our laboratory samples containing glassy or amorphous materials are routinely analyzed and quantified after addition of between 15 and $20 \% \mathrm{Si}$
Table 9. Combining $\mathrm{XRD}$ and $\mathrm{XRF}$ results to calculate an approximate composition of the amorphous component in Fly Ashes.

\begin{tabular}{|c|c|c|c|c|}
\hline & 1 & 2 & 3 & 4 \\
\hline \multicolumn{5}{|c|}{ XRD } \\
\hline Amorphous & 67.84 & 63.64 & 68.41 & 63.81 \\
\hline Calcite & 0.26 & 0.34 & 0.3 & 0.26 \\
\hline Hematite & 0.46 & 0.77 & 0.73 & 0.72 \\
\hline Mullite & 23.91 & 21.46 & 20.52 & 21.88 \\
\hline Quartz & 7.54 & 13.79 & 10.04 & 13.32 \\
\hline \multicolumn{5}{|c|}{ XRF } \\
\hline $\mathrm{CaO}$ & 1.47 & 0.83 & 0.89 & 1.19 \\
\hline $\mathrm{SiO}_{2}$ & 60.9 & 62.3 & 62.3 & 56.8 \\
\hline $\mathrm{Fe}_{2} \mathrm{O}_{3}$ & 4.23 & 4.24 & 4.25 & 4.65 \\
\hline $\mathrm{Al}_{2} \mathrm{O}_{3}$ & 29.8 & 28.9 & 28.9 & 33.9 \\
\hline $\mathrm{MgO}$ & 0.47 & 0.56 & 0.64 & 0.57 \\
\hline $\mathrm{TiO}_{2}$ & 0.29 & 0.29 & 0.3 & 0.31 \\
\hline $\mathrm{Mn}_{2} \mathrm{O}_{3}$ & 0.22 & 0.22 & 0.22 & 0.24 \\
\hline $\mathrm{K}_{2} \mathrm{O}$ & 0.93 & 1.13 & 1.17 & 0.9 \\
\hline \multicolumn{5}{|c|}{ Composition of amorphous component } \\
\hline $\mathrm{CaO}$ & 1.21 & 0.49 & 0.59 & 0.93 \\
\hline $\mathrm{SiO}_{2}$ & 43.796 & 39.926 & 44.052 & 34.728 \\
\hline $\mathrm{Fe}_{2} \mathrm{O}_{3}$ & 4.046 & 3.932 & 3.958 & 4.362 \\
\hline $\mathrm{Al}_{2} \mathrm{O}_{3}$ & 15.454 & 16.024 & 16.588 & 20.772 \\
\hline $\mathrm{MgO}$ & 0.47 & 0.56 & 0.64 & 0.57 \\
\hline $\mathrm{TiO}_{2}$ & 0.29 & 0.29 & 0.3 & 0.31 \\
\hline $\mathrm{Mn}_{2} \mathrm{O}_{3}$ & 0.22 & 0.22 & 0.22 & 0.24 \\
\hline $\mathrm{K}_{2} \mathrm{O}$ & 0.93 & 1.13 & 1.17 & 0.9 \\
\hline
\end{tabular}

powder as described above. Other methods as well as the use of other spike materials have been described by Ward and French (2005). After spiking, the phases are identified and then quantified, using the Rietveld method defining $\mathrm{Si}$ as a standard, which is then used to calculate the amount of amorphous material.

Combining XRD and XRF results, an approximate composition of the amorphous component(s) can be 

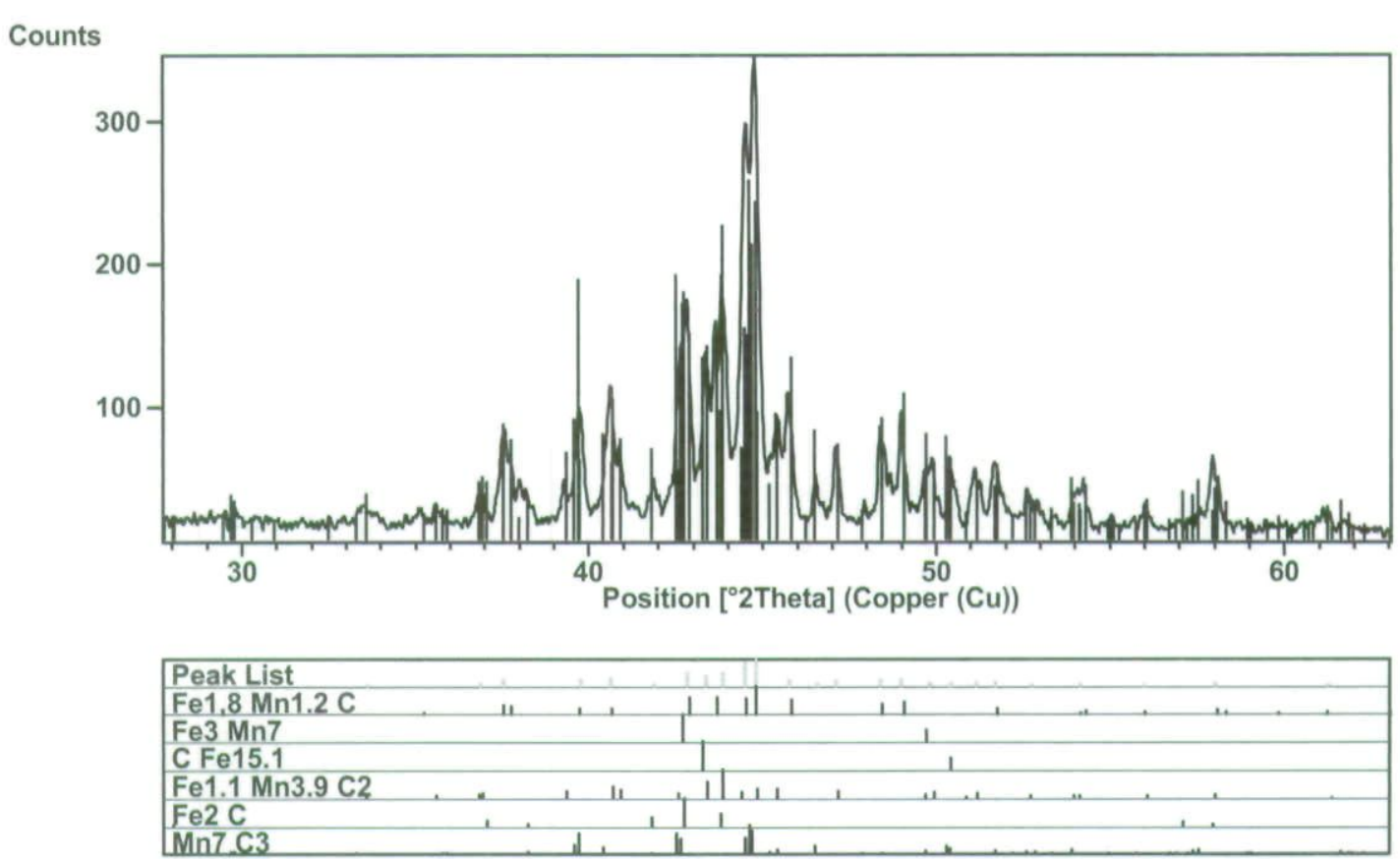

Figure 2. XRD scan of original FeMn sample

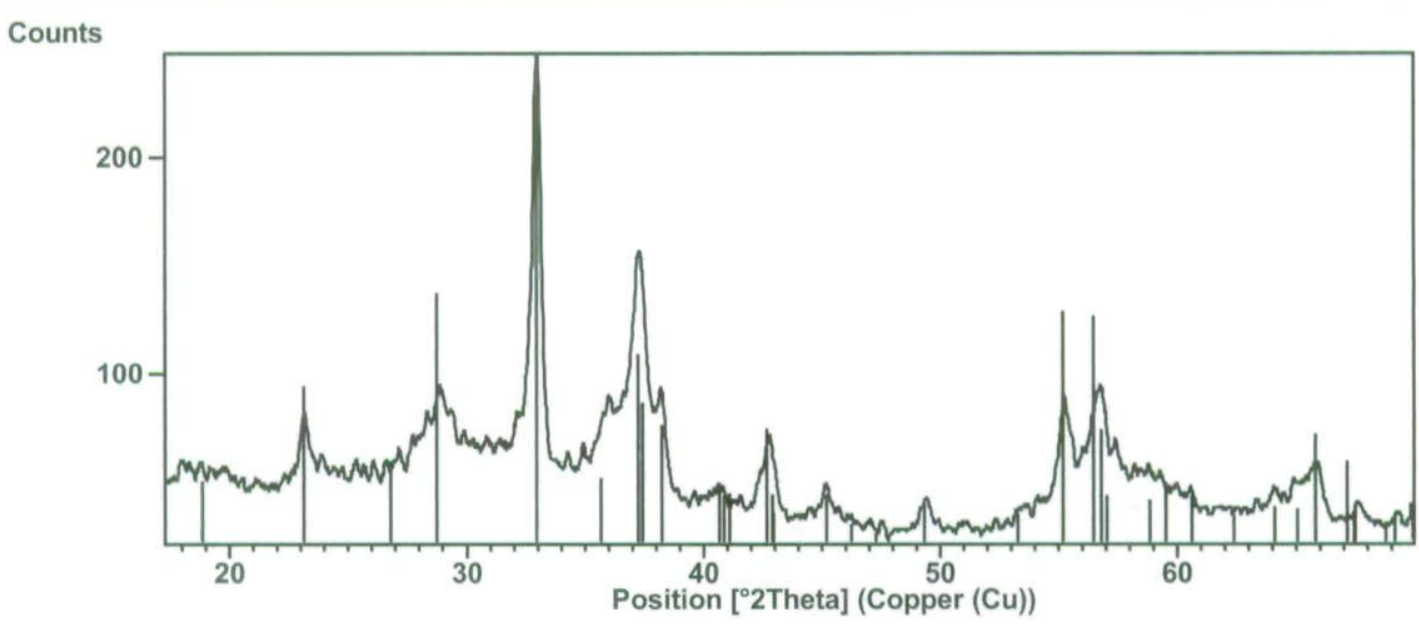

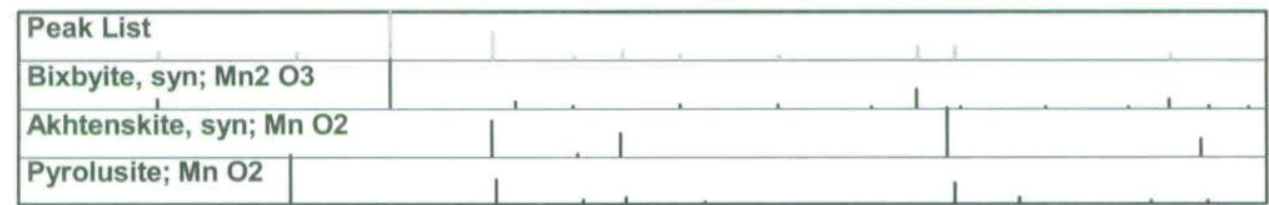

Figure 3. XRD scan of FeMn sample after oxidation with $\mathrm{HNO}_{3}$

calculated as shown in Table 9. The calculations are performed under the assumption that the phases detected have an ideal composition. Care should be taken when dealing with samples where phases may deviate from ideal compositions or show solid solution between 2 or more elements. It would then be advisable to obtain chemical compositions of the individual phases which should be used in the calculations.

\section{Analyses of Ferro Manganese samples}

Ferro Manganese samples that are submitted for analysis usually require fusion preparation methods due to the influence mineralogical effects have on the accuracy of powder briquette methods. Samples are prepared according to the methods described earlier in this paper, and to evaluate the oxidation step, XRD diffractograms were recorded before and after the oxidation step (Figures 2 and 3). It can clearly be seen that the 
Table 10. FeMn fused bead reproducibility.

\begin{tabular}{lcccc}
\hline \% & FeMn fused 1 & FeMn fused 2 & FeMn fused 3 & Avg. \\
\hline $\mathrm{MnO}$ & 80.96 & 80.96 & 81.10 & 81.01 \\
$\mathrm{Fe}_{2} \mathrm{O}_{3}$ & 17.27 & 17.27 & 16.70 & 17.08 \\
$\mathrm{SiO}_{2}$ & 0.21 & 0.21 & 0.24 & 0.22 \\
$\mathrm{P}_{2} \mathrm{O}_{5}$ & 0.10 & 0.10 & 0.11 & 0.32 \\
$\mathrm{SO}_{3}$ & 0.06 & 0.06 & 0.12 & 0.10 \\
$\mathrm{CaO}$ & 0.05 & 0.05 & 0.06 & 0.08 \\
$\mathrm{Cr}_{2} \mathrm{O}_{3}$ & 0.05 & 0.05 & 0.03 & 0.06 \\
Total & 98.70 & 98.70 & 98.36 & 0.01 \\
\hline
\end{tabular}

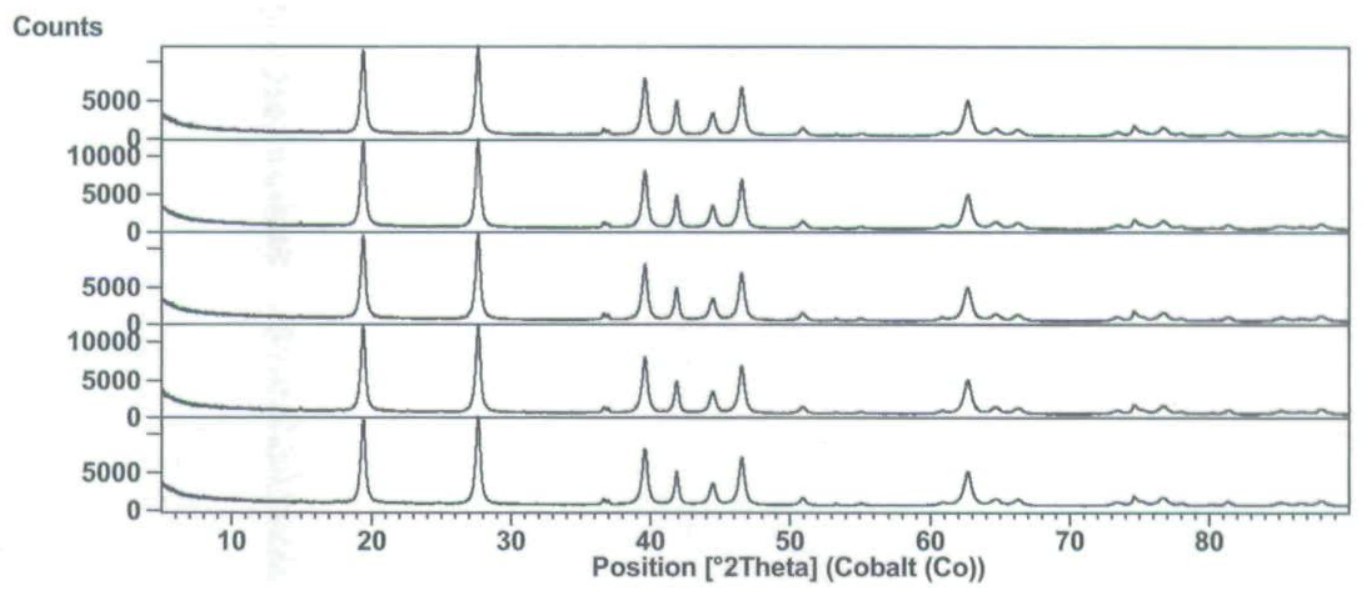

\begin{tabular}{|l|l|l|l|}
\hline Peak List & & \\
\hline Cu ( O H )2; Spertiniite, syn & & \\
\hline Na Cl; Halite & & \\
\hline
\end{tabular}

Figure 4. XRD scans of $\mathrm{Cu}\left(\mathrm{OH}_{2}\right.$ containing samples.

ferromanganese metal phases and ferromanganese carbide phases were oxidised to manganese oxide and ferromanganese oxide phases. Consideration of the results in table 10 shows good reproducibility.

\section{Analyses of Copper salts}

$\mathrm{XRF}$ is routinely used for the quantitative analysis of elements between fluorine and uranium on the periodic table of the elements. Oxygen and hydrogen cannot be determined as their characteristic $\mathrm{x}$-ray photon wavelengths are long and are easily absorbed by air and anything else in the optical pathway. Fluorescence yields for these elements are too low to produce enough photons to be detected. Oxygen is usually assigned in stoichiometric quantities to enable accurate matrix corrections. Hydrogen cannot be determined at all. This could lead to erroneous results where these elements are present. Consider the following Copper salts submitted to the laboratory for analysis. The samples were analysed as pressed powder briquettes (Table 10). As the pressed powder program is calibrated for oxides $\mathrm{Cu}$ will be expressed as $\mathrm{CuO} . \mathrm{CuSO}_{4}$ would be eliminated as a possible composition due to the low $\mathrm{S}$ concentrations, $\left(\mathrm{CuO}+\mathrm{SO}_{3}=\mathrm{CuSO}_{4}\right)$. The analytical totals were very low and a wavelength scan revealed no additional elements. A XRD scan was obtained to determine the phases present and the results shown in Figure 4. From this data the major phase was identified as $\mathrm{Cu}(\mathrm{OH})_{2}$ (Spertiniite), explaining the low analytical totals as a $21 \%$ hydroxide content constituted the difference.

Table 11. XRF Copper salt results (in weight \%).

\begin{tabular}{|c|c|c|c|c|c|}
\hline$\%$ & Sample 1 & Sample 2 & Sample 3 & Sample 4 & Sample 5 \\
\hline $\mathrm{CuO}$ & 34.76 & 33.04 & 32.89 & 34.65 & 34.39 \\
\hline $\mathrm{Na}_{2} \mathrm{O}$ & 30.10 & 31.66 & 32.04 & 30.67 & 31.34 \\
\hline $\mathrm{Cl}$ & 12.53 & 12.56 & 12.22 & 12.07 & 11.77 \\
\hline $\mathrm{CaO}$ & 0.31 & 0.34 & 0.32 & 0.32 & 0.29 \\
\hline $\mathrm{SiO}_{2}$ & 0.08 & 0.04 & 0.02 & 0.06 & 0.08 \\
\hline $\mathrm{P}_{2} \mathrm{O}_{5}$ & 0.04 & 0.07 & 0.05 & 0.03 & 0.08 \\
\hline $\mathrm{SO}_{3}$ & 0.03 & 0.04 & 0.05 & 0.05 & 0.06 \\
\hline $\mathrm{Fe}_{2} \mathrm{O}_{3}$ & 0.01 & 0.02 & 0.02 & 0.02 & 0.03 \\
\hline $\mathrm{ZnO}$ & 0.01 & 0.02 & 0.02 & 0.02 & 0.02 \\
\hline Total & 77.87 & 77.79 & 77.64 & 77.89 & 78.06 \\
\hline
\end{tabular}




\section{Conclusion}

From the above case studies it is clear that a research facility dealing with a wide range of mineralogical samples can hardly function with XRF or XRD instrumentation exclusively. Combined the techniques complement each other and bring a new dimension to the data mining that can be performed. XRF and XRD analysis are each used extensively for the confirmation of results obtained by the other technique. Both techniques are also used to elucidate problems encountered. XRD is an essential tool in method development for XRF sample preparation and XRF results are important for the verification of qualitative as well as quantitative results obtained by XRD analysis.

\section{Acknowledgements}

The authors would like to thank Professor Johan de Villiers invaluable discussion over the last years and for the Iron Ore Sinter data and samples, Professor Richard Kruger is thanked for Fly Ash samples. Kgabo Ramela and the students working in the facility, who patiently prepared and analysed samples to collect the data. The reviewers are thanked for their constructive comments. Dr Thinus Cloete and Dr Geoff Grantham, are thanked for their constructive comments.

\section{References}

Bennett, H and Oliver G. (1992). XRF Analysis of Ceramics, Minerals and Applied Materials. Jobn Wiley and Son, New York, United States of America, $67-93$.

Buhrke, VE, R Jenkins and DK Smith (Editors) (1998) A practical Guide for the Preparation of Specimens for X-Ray Fluorescence and X-Ray Diffraction Analysis, Wiley-VCH, New York, United States of America, 39-58.

Bergmann, J., Kleeberg, R., Haase, A. and Breidenstein, B. (2000). Advanced fundamental parameter model for improved profile analysis. Materials Science Forum, Volumns 347-349(2) 303-308.

Feather C.E. and Willis J.P. (1976). A simple method for background and Matrix Correction of Spectral Peaks in Trace Elements Determination by X-Ray Fluorescence Spectrometry. X-Ray Spectrometry, 5, 41-48

Govindaraju, K. (1984). 1984 Compilation of working values for 170 international reference samples of mainly silicate rocks and minerals. Geostandards Newsletter. 8: Special Issue, 3-16.

de Villiers J and Verryn S (2007). Modern techniques in X-ray diffraction applied to metallurgy. Journal of the South African Institute of Mining and Metallurgy, 107, 83-86.

Kleeberg, R., Bergmann, J. (1998). Quantitative Röntgenphasenanalyse mit den Rietveldprogrammen BGMN und AUTOQUANT in der täglichen Laborpraxis. Bericbte der Deutschen Ton- und Tonmineralgruppe Greifswald, 6, 237-250.

Kleeberg, R. and Bergmann, J. (2002). Quantitative Phase Analysis using the Rietveld Method and a Fundamental Parameter Approach. In: S.P. SenGupta and P. Chatterjee (Editors), Powder Diffraction. Proc. II International School on Powder Diffraction, LACS, Kolkata, India, Allied Publishers Limited, New Delbi, 63-76.

Klug, H.P. and Alexander, L.E. (1974) X-ray diffraction procedures, 2nd Edition, John Wiley and Sons, New York, United States of America, London, United Kingdom, 966pp.

Lachance GR, Claisse F. (1980). A comprehensive Alpha Coefficient Algorithm. Advances in X-Ray Analysis 23, 87.

Lupon D F, Merker J and Scholz F. (1997). The Correct use of Platinum in the XRF Laboratory. X-ray Spectrometry, 26, 132-140.

Sear L G. (1997). The fusion of difficult materials including chromite, cassiterite and reduced sulphur. X-ray Spectrometry, 26, 105-110

Thompson, M. Potts, P.J. Webb P.C. and Kane, J.S. (1997). GeoPT A Proficiency Test for Geoanalysis. Analyst, 122, 1249-1254.

UniQuant $1989 . .2006$ is a registered trademark of Thermo Fisher Scientific Inc.

Ward, C.R and French, D (2005). Relation between Coal and Fly Ash Mineralogy, based on Quantitative X-Ray Diffraction Methods. World Coal Ash (WOCA), April 11-15, Lexington, Kentucky, United States of America. Watson, J.S. (1996). Fast, Simple Method of Powder Pellet Preparation for XRay Fluorescence Analysis. X-Ray Spectrometry, 25, 173-174.

Willis, J.P. and Duncan A.R. (1993), Computer Program "TRACE" for information contact Associate Professor Andrew Duncan. Geological Sciences Extension Building, Room 224, University of Cape Town, Private Bag, Rondebosch 7701, South Africa.

Willis, J.P. and Duncan A.R. (2008), Understanding XRF Spectrometry. A training course in XRF Spectrometry. PANalytical B.V., Netherlands, p. $9-9$

Young, R.A. (Editor) (1993) The Rietveld Method, International Union of Crystallograpby, Monographs on Crystallography, 5, Oxford Science Publications, 298pp.

Editorial handling: A. Bumby 
Copyright of South African Journal of Geology is the property of Geological Society of South Africa and its content may not be copied or emailed to multiple sites or posted to a listserv without the copyright holder's express written permission. However, users may print, download, or email articles for individual use. 